\title{
Performance Incentives To Increase Motivation; Potentials Of Meaningful Activities In Project Management
}

https://doi.org/10.21272/sec.4(4).95-118.2020.

Dirk Zwerenz, ORCID: https://orcid.org/0000-0001-8677-6050

$\mathrm{PhD}$ Candidate, University Kaposvár, Hungary; Head of Major Project Service, German Doka formwork technology GmbH, Maisach, Germany

\begin{abstract}
Performance incentives to increase motivation; potentials for meaningful activities in project management, the author will concretize this with meaningful activities in project management.

The ideal project leader is described by Mark Twain in his novel "The Adventures of Tom Sawyer" (Twain, 1876) in the episode of Tom Sawyer painting the fence. Tom is able to motivate his friends for the actually boring activity in a way that they are willing to support him voluntarily. Regarding the law of human action discovered by Tom Sawyer, Mark Twain states: "To awaken a person's desire, all that is needed is to make the object difficult to reach" (Twain, 1876). In 2006 Ariely, Loewenstein and Prelec examined the rules of irrational action described by Twain. They conclude that individuals make decisions based on their intrinsic motivation and sometimes not on "what is reasonable" (Ariely, Loewenstein, \& Prelec, 2006).

This enthusiasm of a project leader is transformed in this article and is reflected as a component "project brand strength" in the performance assessment of a project leader (Zwerenz, 2019). The author's experience as a project leader in the implementation of several major projects also takes up this enthusiasm and expands it to include the identification of the project teams with themselves and the aspect of meaningful activities as an incentive in project management. That identification and motivation are on the one hand necessary to enjoy one's profession seems understandable, on the other hand the boundaries between vocation and exhaustion are quickly crossed. Schmalenbach describes this in the article "Sacrifice of passion" in "DIE ZEIT", issue 2-2019 with the provocative sentence "If you break down, you are a better person". Committed project managers develop a very similar passion for "their" project and thus a comparable identification with their profession.

The tension between income, recognition and prosperity is discussed. Furthermore, the dependencies of meaningfulness, recognition and income are derived from the literature and presented as factors influencing personal well-being.

Finally, this article contributes to the design of a motivating variable remuneration system for project managers and other exposed occupational groups.

Keywords: variable compensation, value management, development of individual competences, knowledge management, team management, management of individuals - development, motivation and reward, leadership, management of stakeholders, management of human resources, engineering and construction, research theory on project management.
\end{abstract}

JEL Classification: A14, D01, D21, J62.

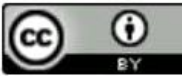

This work is licensed under a Creative Commons Attribution 4.0 International License.

Cite as: Zwerenz, D. (2020). Performance Incentives To Increase Motivation; Potentials Of Meaningful Activities In Project Management. SocioEconomic Challenges, 4(3), 95-118. https://doi.org/10.21272/sec.4(4).95118.2020.

(C) The Author, 2020. This article is published with open access at Sumy State University. 
SocioEconomic Challenges, Volume 4, Issue 4, 2020

ISSN (print) - 2520-6621, ISSN (online) - 2520-6214

\section{Introduction}

\section{The power of the great cause}

The power of the great cause - feelings of happiness and meaning. Football World Cup 2006, semi-finals Germany - Italy, Germany loses. The three-time world and national goalkeeper Oliver Kahn, also known as "the Titan", only enters the World Cup as number two behind his team chamberlain (and rival) Jens Lehmann. Only in the small final for 3rd place the overzealous, egocentric Kahn is allowed to enter the goal. He later says, "I always wanted to win, my whole life was geared towards winning". The substitute bench during the World Cup was "the highest penalty" for him (Schnabel, 2019). But when he entered the stadium during the consolation game and experienced the euphoria of the fans and the enthusiastic cheers, he realised that he was not playing for himself alone, but for a whole country. Looking back, Kahn formulates this experience in the following words: "Subordinating oneself to something greater than one's personal destiny and not walking around all day with an 'offended liver sausage face' cannot harm one's own development" (Schnabel, 2019). Adapted to project management, Kahn's description means; subordinating oneself in the project team to the project goal - identifying with it seems to be more important than personal moments of success.

From March 2002 to October 2005, the author worked as project manager of a project-relevant construction supplier on the new construction of the Leibis/Lichte dam (Thuringia). The aim of the overall project was to supply around 300,000 inhabitants of Thuringia with treated drinking water from 2005. The planning, including the resettlement measures, goes back to the 1980s. In the case of a prestige project such as this, probably the last new dam to be built in Germany in the foreseeable future, the companies involved are concerned not only with the monetary profit targets but also with the media-effective marketing of such a construction measure. As a young civil engineer, the prospect of taking on such an exposed project management function offered a unique, irretrievable, highly motivating and above all meaningful opportunity. A permanent presence on site was required. Even the separation from the family was gladly accepted due to the pride of the transferred responsibility. Such meaningful challenges do not often present themselves to a young civil engineer, which in retrospect further increased his own motivation and enjoyment of the task. Before the candidate agreed to take over the project management, personnel interviews were held on the general conditions offered by the company. However, the urge to take over the project management completely overlooked the question of a possible adjustment of the monthly salary. All that counted was the will for the meaningful and sustainable prestige project.

\section{Literature survey}

In recent years, two issues of relevance to the economy have developed which will be examined in more detail in this paper. On the one hand, many articles have been published about the necessity of implementing project management in medium-sized companies and the career opportunities and income development through project management that are associated with it for the employees. On the other hand, a lot of articles have been published on the topics of motivation of employees, incentive systems for employees and performance behavior of employees in project teams. The publications on the topic of motivation are complemented by a large number of publications on the topic of mental stress and the creation of meaning in the world of work.

Superficially, the two disciplines of $>$ project management $<$ and $>$ incentive system for motivation $<$ do not seem to contradict each other at first glance, let alone multiply. However, a closer look reveals considerable contradictions with regard to the intended, intended and above all the unintended consequences generated by variable remuneration systems for the motivation of project participants. For example, wrongly set incentives can have counterproductive effects on the internal motivation of employees and have considerable consequences for the company and its corporate culture (McKevitt, Carbery, \& Lyons, 2017). Project-oriented companies often work in complex economic sectors, so project managers usually have to orient themselves in networks of dependencies. Counterproductive behavior induced by incentive factors can have far-reaching effects in the company itself and on the market. In the theoretical extreme case, false incentives could influence the economic success of companies. The moment project managers place their project at the center of their actions and ignore the serviceable framework conditions of the entire company, it may be possible to successfully achieve an 
individual project goal - but at the same time the company could be damaged by individual over motivation from within. The question must therefore be answered;

- What behavior should be provoked in the project manager by variable remuneration components (extrinsic motivation), what real consequences can this have on the intrinsic motivation and the actual actions of the project manager?

The publications on the topic of motivation of (project) staff are complemented by a wide range of articles on the topic of mental stress in the world of work. Particularly in the career development of young project managers, the complex interplay of diverging project circumstances, depending on individual developmental stages, must be adequately taken into account (V. C. Haun, 2019). Haun explains that a certain dynamic is created by a complex interplay of stressor and resource constellations and individual working conditions (V. C. Haun, 2019).

Relevant boundaries between the various categorizations are fluid. For a better overview, the results of the literature search were divided into the following three self-defined categories and discussed in detail in the following chapters.

- Literature research on incentive systems and variable remuneration.

- Literature research on meaning and psychology.

- Literature research on questions of human resources development.

\section{Literature research on incentive systems and variable remuneration}

According to our own research, the research field of incentive systems offers only limited adaptable literature specifically for project management. Research into psychological aspects of the implementation of incentive systems in project management is marginal. The listed results of the literature research on incentive systems provide the basis for further research.

Comprehensive empirical basis of the effects of extrinsic rewards and their consequences on intrinsic motivation published in 1999 Deci, Ryan and Köstner in the Journal Psychological Bulletin (Deci, Ryan, \& Koestner, 1999). The authors review older meta-analyses and compare them with their own surveys. The chapter $>$ Extrinsic versus intrinsic motivation< goes into this in detail. The disadvantage of the comprehensive studies is that only children, adolescents and students were interviewed as test persons and thus the transferability to project management and thus to the economy can only be assumed but not scientifically proven.

In 2000, Schulz \& Schulz describe immaterial incentives as an instrument of corporate management and use efficiency criteria to examine the effect of soft factors of management responsibility (Schulz \& Schulz, 2000). In the same year, Ryan and Deci describe the effect of how intrinsic motivation can be used to describe natural commitment and how the extrinsic counterpart manifests itself in external influence or externally controlled selfregulation. In addition, the effects on autonomy and personal responsibility are discussed in this context (Ryan \& Deci, 2000). In 2006, Sabine Fließ is researching suitable incentive systems of distribution policy in market and product management (Fließ, 2006). Hertel and Lauer describe the future of leadership and the sensible use of incentive systems in 2012 (Hertel \& Lauer, 2012) and in the same year Grösser deals with the dynamic complexity of leadership and describes it as: "the great challenge for management" (Grösser, 2012).

In 2015, the >GPM Deutsche Gesellschaft für Projektmanagement e.V.< will publish a study on the dependence of salary and career (Schoper \& Schaden, 2015), but in this study the questions of an individual-personalized variable remuneration system will only be dealt with rudimentarily. The management consultancy Kienbaum will present an interesting trend study on performance development in 2017 (von Hülsen \& Kopiske, 2017), but even in this study the adaptability of variable remuneration systems to the specifics of project management remains diffuse.

Furthermore, Frey and Osterloh (alone and in conjunction with other colleagues) provide several studies, metaanalyses and publications on the complex of incentive systems (Frey \& Osterloh, 1997, 2000, 2002; Osterloh \& Frey, 2000), but also largely without adaptability to the specifics of project management. 
In 1993, Gary S. Becker, in his article > The Economic Way of Looking at Behavior< (Becker, 1993), describes a new economic approach in which individuals are motivated solely by selfishness or material gain. Becker extends traditional theories of social analysis by opening the perspective of individual choice to the micro level. He describes it as a "powerful" tool for deriving implications at the group or macro level. He illustrates his approach with examples from his previous current work in a lecture for the award of the Nobel Prize. Becker's analyses assume that individuals maximize well-being as they see it, regardless of whether they are selfish, altruistic, loyal, malicious or masochistic. He further describes that:

- Quote "The most fundamental limitation for economic decisions is the limited time of life" (Becker, 1993).

Becker puts forward the thesis that the growing wealth of goods reduces the value of additional goods and, conversely, that time is becoming increasingly valuable. In doing so, he indirectly lays the intellectual foundations for Kahneman and Deaton's research (Kahneman \& Deaton, 2010). Basically, Becker reduces human thoughts driven by emotion to rational economic considerations. He demystifies alleged ethical / altruistic actions into purpose-driven actions. This approach understandably provides multiple points of attack for discussions and bears the danger of misunderstandings. A particularly great danger is posed by quotes from Becker's paper that have been taken out of context. For this paper, this publication provides fundamentally important approaches to understanding the motivation for behavioral change. Becker's research provides, among other things, the theoretical foundations for a motivating and meaningful incentive system for project managers.

In 2013 Armin Falk and Nora Szech describe a further, quite critical perspective on motivation and incentive systems in the broadest sense in their article > Morals and Markets< (Falk \& Szech, 2013). The two researchers sought the answer to the question whether the market destroys morals. The participants in a high-profile experiment were to decide whether they would commit a sin in a world of supply and demand for money. Falk and Szech wanted to find out why people put their own moral values in the background depending on the situation. Their thesis:

- The market tempts us to act immorally because it creates a distance between our decisions and their consequences (Falk \& Szech, 2013).

In spring 2012 Falk and Szech conducted their experiment in the Beethovenhalle, the Bonn concert hall directly on the Rhine. The individual participants were placed in front of a screen and given the choice of winning ten euros and sentencing a mouse to die in return - or giving up the money so that the mouse could survive.

The result of Bonn's moral experiment: on their own, 45 percent decided to take the money, in the market negotiations it was 75 percent. Even 45 percent is quite a lot, after all, 10 euros don't mean the world to a student. But the main difference is the difference to the market, where many more participants decided against morality. Moreover, the so-called sellers no longer automatically received 10 euros. The average price was only 6.40 Euros and sank further from round to round of the experiment. In the end, the sellers gave away the lives of the mice for less than five euros on average. So the morale in the market situation was lower from the beginning than in the individual decisions, but it apparently deteriorated even further with time.

The experiment shows in a way that is as simple as it is sensational: The market sometimes makes it very easy for people to push morality and sense aside. In retrospect, the question aroused controversy among economists as to whether the effect of the market actually came to the fore in the experiment - or whether it was simply that people hid in the group (acted anonymously). To want to stimulate the personal commitment of project leaders to achieve the project goals by monetary means naturally carries the danger that the morale of project leaders will suffer in favour of their own advantages from their own hopes of getting a bonus. A meaningful and sustainable incentive system must consequently be built up very sensitively and applied and controlled responsibly.

In addition to Karl Max (Marx, 1887), the Gossensche Laws (Jerger, 1993; Piekenbrock, 2016) are diagnosed as further basic scientific literature and described in detail in the chapter on "Income, Recognition and Well-being". The question of relative income levels and saturation value was described by Suntum in reference to Plato and rounded off with Thünen's formula for fair wages, or at an optimal wage rate (Suntum, 2005). In 2005 Wilson 
and Gilbert describe the psychological process of "Affective Forecasting" (Wilson \& Gilbert, 2005). They argue that most people base many of their decisions on affective forecasting, and thus their actions are due to a distorted effect of their emotional identity. As a result, many people find it difficult to acknowledge a clear view of the impact of their thoughts and feelings in terms of predictable reactions, which would counteract the desired effect of incentive systems.

Daniel Kahneman and Sir Angus Deaton provide the most far-reaching research of all in their highly regarded article > High income improves evaluation of life but not emotional well-being< (Kahneman \& Deaton, 2010). Rose also describes that at the upper end of the income scale, the pursuit of wealth can also have a negative impact on life expectancy (Rose, 2016). However, Rose also points out that when assessing the individual satisfaction of people, it is not the absolute amounts that matter, but rather the relative relationship in the environment of the test persons that is significant for their well-being.

Wetzker and Strüven explain the relationship between absolute and relative amounts in 2016 (Wetzker \& Strüven, 2016).

In the same year, the second edition of Kieser's practical paper on >Variable remuneration in sales, 10 building blocks for motivating remuneration in field and office work< (Kieser, 2016) is published. Kieser analyses ten, in his view, motivating components of variable remuneration in sales with regard to their mutually reinforcing effect. He evaluates this using nine case studies from different industries, but from the primary perspective of sales.

Patrick Kampkötter is particularly active in the field of research into pecuniary incentive systems and their consequences for the satisfaction of employees' needs. Together with various colleagues, he publishes various articles on the topic described; Measuring the use of human resources practices and employee attitudes: The Linked Personnel Panel (Kampkötter, Mohrenweiser, Sliwka, Steffes, \& Wolter, 2015); Performance appraisals and job satisfaction (Kampkötter, 2014); Differentiation and performance: An empirical inves-tigation on the incentive effects of bonus plans (Kampkötter \& Sliwka, 2011) and Forschungsbericht 507, Bericht zum Forschungsmonitor "Variable Vergütungssysteme" (Slimka, Kampkötter, \& Grunau, 2018). In the articles and publications, Kampkötter and a large number of colleagues analyses and describe the effects of variable income on the willingness of employees to perform. However, they do not go into detail about the specifics of project management and the special needs of project managers.

Kohn, Frey/Osterloh, Pfeffer" and to a large extent Dressler enrich the controversy in personnel management policy with particularly critical contributions on the counterproductive effect of variable remuneration (Dressler, 2000; Frey \& Osterloh, 2000; Kohn, 1994; Osterloh \& Frey, 2000; Pfeffer, 1998). Under the heading >Stimulus bonus - sense or nonsense of variable compensation<, "Krieg" discusses the effects of variable compensation from different perspectives (Krieg, 2010).

In addition to micro-economic and macro-economic personnel strategies, variable remuneration systems in project management pose a particular challenge due to the requirements for interdisciplinary company-wide cooperation. In the chapter on "marginal utility of variable remuneration systems", which follows later, the opposing views are discussed in more detail.

\section{Literature research on meaning and psychology}

The exploration of the dimensions of meaning and the different forms of sense perception are relevant for understanding the team building process.

The psychologist and researcher at the University of Innsbruck Tanja Schnell lists various dimensions of meaning. These are reason, morality of tradition (dimension "order") community and care (dimension "we and well-being") and the classical dimensions religion, spirituality, self-knowledge or closeness to nature (Schnell, 2016). For project management, the meaningful team spirit and the integration of one's own demands into an overriding and meaningful goal means that a project goal can give the person concerned more personal meaning than personal success. Even, or especially in crisis situations, people can be encouraged to persevere in the most adverse circumstances by the sense of the matter, as Viktor Frankl has described autobiographically (Frankl, 2010). 
However, as the research of Schnell and Pollet (Pollet \& Schnell, 2017) shows, the challenge for the project manager is to make the meaning of the project goal clear to the project team. The way in which meaning is created depends on the social talent of the project leader and the individual experience of the project team members. The creation of meaning is therefore a major challenge in the context of this research. Once the team has understood the meaning of the project, it will also be ready to do everything possible to achieve the project goals.

The examined literature from the field of psychology exceeds the limits and use cases relevant to project management immensely. Nevertheless, the research area of psychology has contributed significantly to the understanding of the effects of good leadership in project management. In 2009, researchers Moser, Galais and Byler describe the effects of personnel psychology specifically in project management (Moser, Galais, \& Byler, 2018). Their findings lay the foundation for further research. In 2018 Kraus \& Woschée describe in two essays the areas of project team building and understanding, the need for common goals in project management (Kraus \& Woschée, 2018a, 2018b). As early as 1999, Hauschild dealt with resistance to innovation (Hauschildt, 1999). Sydow and Langhoff \& Schröder focus on these issues and describe the necessity of cooperative action in projects and areas of innovation competence (Langhoff \& Schröder, 2015; Sydow, 2012).

Cognitive organizations, procedural and functional design of companies will be described by Haun in 2016 (M. Haun, 2016). In 2011 Bemmé describes the human success factor in cultural project management and places the human being (the project manager and his project team) at the centre of the success or failure of a project (Bemmé, 2011). Empirical results from three individual case studies will be put into the context of balance sheet-oriented management by Kühl in 2016 and discussed in terms of their effectiveness (Kühl, 2016). In 2018, Brodbeck \& Guillaume have endeavoured to summarise the research findings to date on the handling of information and opinion formation in projects in a manual for successful leadership in project management (Brodbeck \& Guillaume, 2018).

Thaler 2000 sheds light on a fundamentally critical aspect of predicting human behaviour in his article $>$ From Homo Economicus to Homo Sapiens< (Thaler, 2000), for which he will be awarded the Nobel Prize for Economics in 2017. Thaler explains that predicting human behaviour is complicated and influenced by one's own experiences, learning, background and upbringing. He thus competes against some well-known economists of the first half of the 20th century (e.g. Irving Fisher, John Maynard Keynes) who call people "hyper-rational" beings. The article builds on the history of economics and extrapolates from early economists to modern economic theory. In doing so, Thaler integrates results of then modern research. The main findings of the article in the context of this article are

- Decisive for the irrational and emotional decisions of people is their limited rationality and the transfigured memories during follow-up treatments of the consequences of decisions made (Thaler, 2000).

- Human behaviour cannot, or can only to a limited extent, be predicted with rational calculation models (Thaler, 2000).

For this research, Thaler's article means that the behaviour and working methods of project managers will only be controllable in limited areas and that interpersonal, personal and emotional aspects will always have to be taken into account in the personnel management of project managers and the purpose of the project. Management by reward model alone will certainly not work.

\section{Literature research on questions of human resources development}

The scientific articles on personnel development topics accompany all areas in the company where personnel are deployed. For this publication, only limited sub-areas of personnel development will be covered in the following, but nevertheless significant sub-areas in some points. Research on personnel development is relevant for understanding the team building process.

In 2005, Ryschka and colleagues will provide tools and techniques for personnel development that are also relevant to project management (Ryschka et al., 2005). A year later, Siebert describes the management systems between stability and change in the study >Leadership Excellence< (Siebert, 2006). In 2008, Edwin Tom, Stephan Uske and Karl Lindenberg will focus on the particularities of personnel management, which are particularly 
evident in matrix organisations, and the diagnosis of the progress of further training of employees sent to the project team (Tom, Uske, \& Lindenberg, 2008).

The > Handbook of the Sociology of Work < written by Windeler \& Wirth in 2010 offers decisive approaches to the team-building issues to be researched in the course of this scientific work (Windeler \& Wirth, 2010). Windeler \& Wirth conduct a discourse on networks and work, differentiating between structural network analysis and the classical steering approach as a form of management. Essential aspects of social learning and collective memory have currently been described in 2018 by Felix Brodbeck and Yves Guillaume (Brodbeck \& Guillaume, 2018). Brodbeck and Guillaume are concerned with, among other things, the construction of transactive knowledge systems and take the view that the development of specific knowledge is favoured by strong networking within the project team (Brodbeck \& Guillaume, 2018).

The listed research results on personnel development processes are relevant for considerations of the constellation of authority, especially the mechanisms of the team building process in the context of this thesis. In the author's opinion, meaningful participation in projects offers inexperienced colleagues an adequate opportunity for personal development in challenging, practical and meaningful situations.

\section{Research gap}

The previous chapter > literature survey< analyzed and discussed research results from different, not entirely overlapping subject areas. Each research discipline, viewed singularly, provides a variety of answers to the elementary challenges posed by the respective subject. For the interdisciplinary field of project management, the contradiction between tools for motivating project leaders and a non-contra-productive incentive system in project management, while at the same time creating meaning, has not yet been satisfactorily addressed. Atkison, Crawford and Ward described the fundamental uncertainties in project management in the International Journal of Project Management in 2006 as "encompassing lack of information, ambiguity, characteristics of project participants, compromises between trust and control mechanisms" (Atkinson, Crawford, \& Ward, 2006) and thus give a detailed account of the complex challenges a project manager is confronted with on a daily basis.

The following figre visually describes the research gap extracted from the literature search.

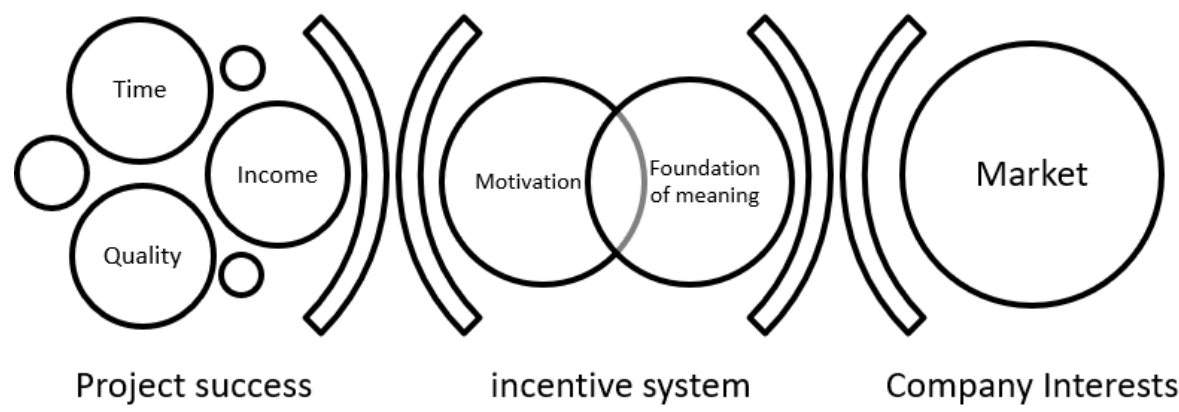

Figure 1. Representation of the research gap from literature research

Source: own representation.

\section{Hypothesis}

As an introduction to this scientific work, the project $>$ Leibis/Lichte Dam< is briefly presented. The project team lived and worked for about 3 years on the common goal >the construction of a dam<. Even today, 18 years after the laying of the foundation stone, the so-called "Leibis-Meeting" still takes place every year on the first weekend of September. In the meantime, not only the former project team members take part in the annual meeting, but also their wives and children, and lately even friends and relatives of those directly involved. The questions that can be derived from this example:

- What are the binding forces that motivate those involved?

- What sense do the parties involved see in this? 
Assumptions:

From my own experience as a project manager and my regular participation in the meeting, I deduce that it is the common stories that are told again and again, it is the imponderables that had to be overcome together and finally it is the pride and the sense of unity that we have contributed to the project.

- In the end, it is probably the purpose of the new building > Leibis/Lichte dam<.

a) theses:

The considerations discussed so far and the explication of the state of research in the previous chapter allow the derivation of the following theses:

T 1) Motivated project managers have a decisive influence on the success of the project.

T 2) The motivation of project managers can be increased by extrinsic incentives.

T 3) The presentation of the meaning of the project is elementary for the formation of the project team and is a core task of a project manager.

T 5) The people working together in a project must be inspired for the project in order to grow together to form a project team and recognise its purpose.

T 6) Employees who identify themselves with a project and the team are prepared to provide the highest personal service to the project.

\section{b) hypothesis:}

From the theses derived above I make the following hypothesis:

H 1) A project must be established as a meaningful task in the company in order to facilitate the identification of the employees with the project and team building. The project manager has to take over the function of the sense ambassador of his project within the company and outside the company.

\section{Aim of this scientific publication}

The aim of this publication is to create basic algae of a variable remuneration system for project managers in the German construction industry and the construction supply industry.

\section{Practical relevance}

In 2000, Schulz analyzed various incentive systems in the context of corporate culture and corporate image (Schulz \& Schulz, 2000). He describes that negative incentives of poorly configured remuneration systems can lead to the exclusion of project team members depending on the variable characteristics and the degree of hierarchy and can also have suboptimal consequences for the corporate culture (Schulz \& Schulz, 2000). He further describes that incentive systems must be embedded in the respective corporate context or corporate philosophy with their primary and secondary effects. Accordingly, the embedding of a variable remuneration system must correspond to the corporate culture and corporate image and be adapted to redundant existing corporate benefits, such as voluntary social benefits of the company, local environments and other intangible incentives.

At the same time, poorly adjusted incentives can trigger counterproductive effects in the company itself and in the market environment. The context, low-threshold induced incentives and immoral actions in anonymous environments have been demonstrated in a very tangible way by Falk and Szech in their Bonn experiment, thus revealing the counterproductive side of incentive systems (Falk \& Szech, 2013).

Under current socio-political aspects, the creation of attractiveness as an employer for existing and future employees and a sustainable personnel policy could be generated as important criteria for companies.

\section{Methodology and research methods}


The qualitative research method is used for this scientific work. Goldenstein and his research colleagues describe the following: "Qualitative research investigates connections and phenomena in the environment and the situation" (Goldenstein, Hunoldt, \& Walgenbach, 2018). It also describes situations in which regular perceptions or their reproduction as a form of "transcribed observations" (Goldenstein et al., 2018), statements in the form of interviews and information from websites, press releases involving social actors (Goldenstein et al., 2018). The central concern of the qualitative studies is the question of the "why" and thus the "understanding of phenomena" (Goldenstein et al., 2018). In contrast to quantitative research, qualitative research is based on models established at the beginning of the research process. Models and hypotheses are analyzed for correlations between them, and these are conceptualized in order to evaluate the constructs and theories.

\section{Outcomes}

\section{a) Marginal utility of variable remuneration systems:}

Kieser understands > variable remuneration< to mean: "a significant, i.e. noticeable, income component that depends on the achievement of objectives by the employee or a small team" (Kieser, 2016). In Kieser's view, the employee should be involved in various performance targets and be able to influence these directly in his or her personal field of activity (Kieser, 2016).

Amelung describes the three basic functions of a remuneration system; distribution function, control and incentive function and an innovation function (Amelung, 2019). He further explains that the distribution function of a remuneration system should be guaranteed by a performance-related income of the service providers while at the same time minimizing the burden on the service financier (Amelung, 2019). With regard to the control and incentive function relevant for this publication, Amelung describes the "considerable incentive function on the type and extent of the service provision" (Amelung, 2019). He justifies this statement with the "target income hypothesis" which he describes in his statement. The term "target income hypothesis" is not found in the relevant literature, but in the opinion of the author it probably goes back to the origins of the "income elasticity" according to Ernst Engel $(* 1821 ; \uparrow 1896)$ and the "income hypothesis" according to John Maynard Keynes $(* 1883 ; \dagger 1946)$. In 1857, in his contribution to the journal of the Statistical Bureau of the Royal Saxon Ministry of the Interior $>$ The Production and Consumption Relations of the Kingdom of Saxony<, Engel describes for the first time at the microeconomic level the law that the proportion of income spent by a private household on consumer goods decreases with increasing income (Engel, 1857). Engel's law, which is derived from this, is considered to be the best-supported empirical law in economics.

In 1937 Keynes described his income hypothesis on consumption and savings behavior and differentiated into an absolute, a relative, a permanent income hypothesis and a life cycle hypothesis (Keynes, 1937). From a macroeconomic perspective, he argues that the demand for consumer goods depends on numerous subjective and objective factors. Keynes describes expectations, personal preferences and individual aversions as subjective (soft) factors. According to Keynes, objective factors include absolute and relative income levels and income distribution.

In 1946 Simon Kuznets takes up Keynes' idea in the >consumption function< and describes it empirically, in terms of its long-term constants (Kuznets, 1946). In simplified terms, consumption continues to increase with rising income, up to a certain threshold value. However, Kuznets assumes that when income rises above the threshold, the average consumption rate falls in favour of a higher savings rate (the level of the threshold is not discussed here). The special incentive effect of variable compensation on employee motivation can be derived from Keynes' > Fundamental Psychological Law < (Keynes, 1937) as part of the absolute income hypothesis. Keynes describes: "Since the main background of subjective and social incentives therefore changes slowly, while the short-term influence of interest rate changes and other objective factors is often of secondary importance, we fall short of the conclusion that short-term changes in consumption depend largely on changes in the income rate ( ....) and not on changes in the propensity to consume from a particular income. (Keynes, 1937). 
If the term "consumption behavior" used in this quotation is substituted with "motivation to satisfy needs", which is figuratively implied according to Maslow (Maslow, 1943) and Herzberg (Herzberg, 1968), the following statement is applicable to this research;

- A moderate increase in the income of project managers has only a minor effect on the motivation and behavioural changes of a project manager, whereas countercyclical (project-dependent) variable remuneration components can have a motivating effect on the project manager.

In their company and employee survey >Monitor Variable Remuneration Systems $<$ published in 2018, Kampkötter and colleagues define variable remuneration as the "performance-related part of total remuneration" (Kampkötter, Sliwka, Butschek, Petters, \& Grunau, n.d.). They further explain that the deferred variable payments are the part after "the result of the work or the success of the company is foreseeable" (Kampkötter et al., n.d.). Kampkötter and colleagues also describe that variable compensation systems are often used "to motivate employees to perform better and to share in the company's success" (Kampkötter et al., n.d.). The authors of the study point out that variable remuneration systems are used as part of the salary in about $60 \%$ of all companies surveyed. The percentage of variable remuneration varies between $13 \%$ and $18 \%$ of the basic salary, depending on the management responsibility and the sector under investigation (Kampkötter et al., n.d.). Personal success, company success and team performance are cited as the basis for assessment. With regard to the design of variable remuneration systems, Kampkötter's studies indicate that monetary incentive systems only have a motivating effect "if they are not directly formula-based" (Kampkötter et al., n.d.), i.e. they simply have to be designed.

This suggests the conclusion that soft incentive factors must make up a not negligible motivational part of the variable remuneration system, as Wetzker and Strüven have clearly pointed out in their description of the strategic management process (Wetzker \& Strüven, 2016).

According to Kieser, the amount of variable remuneration (in line with the one described above) is based on the degree to which targets are achieved (Kieser, 2016). It describes a "normal" share of $30 \%$ for field sales staff and an approach of 10\%-20\% for office staff (Kieser, 2016), but no approach for project managers. At least for sales he advises that: "Overfulfilment of targets leads to significant additional income, underfulfilment of targets must lead to a loss of income" (Kieser, 2016). The extent to which this can also be transferred to the project management of the respective country in terms of labour law, however, remains open.

Variable remuneration systems are establishing themselves in tandem with an increasing participation of employees in the company's success, which has been rising steadily in German companies since around the mid1990s. Authors such as Bender, Tondorf and Bahnmüller have taken up this issue in social science publications (Bahnmüller, 2001; Bender, 1997; Tondorf, 1996). These new forms of incentive wages have also been described in economic research (Blinder, 1990; Schares, 1993), whereby the authors primarily dealt with the economic effects on profit and capital participation. In the personnel management literature at the time, the Deutsche Gesellschaft für Personalführung e.V. (https://www.dgfp.de/) discussed the effects of variable remuneration on remuneration systems (Eckardstein \& Janes, 1995; Nagel \& Schlegtendal, 1998). Eckardstein and Janes described the employers' motives for introducing variable remuneration systems with the aim of "making wage costs more flexible and allowing greater differentiation in employee performance" (Eckardstein \& Janes, 1995). In 1997 Heywood and colleagues looked at the possibilities of indirect performance control, which offer employers these possibilities through the introduction of variable remuneration (Heywood, Siebert, \& Wei, 1997). From the employer's perspective, employees should be motivated by individual performance incentives in order to increase the success of the company as such.

From a strategic corporate perspective, these considerations seem quite reproducible, but some authors describe the project-specific consequences of these approaches quite critically. Nerdinger is particularly critical of the connection between material incentives of variable remuneration and an increase in motivation on the one hand, and the connection between high motivation and above-average productivity on the other (Nerdinger, 1995). The following paragraphs describe the problem in more detail. 
In many companies, many managers and other executives receive part of their remuneration in variable parts of their salary. The research report $507>$ Report on the research monitor "Variable compensation systems" $<$ of the Federal Ministry of Labour and Social Affairs (Slimka et al., 2018) shows that around 60\% of all companies in Germany per se apply compensation systems with variable components. The report also describes that primarily employees with management responsibilities benefit from variable remuneration. According to the report, the level of variable remuneration for managers is often based on the earnings targets of the entire company, although a differentiated consideration of short and long-term company targets is applied in a variety of calculation models. The percentage of variable remuneration has been empirically determined by various authors. In their report on the research monitor "Variable compensation systems" (Slimka et al., 2018), Slimka and colleagues describe a share of around 18\% (measured as a percentage of basic salary) in 2018, depending on management responsibility, the industry and the consideration of team and/or individual performance. This percentage seems relatively low at first glance, but with a sample size of $n=266$ and an observation period from 2012 to 2016 it can certainly be verified.

Schwaab and colleagues describe a conversion of up to 35\% (Schwaab, Bergmann, Gairing, \& Kolb, 2010) of the remuneration into bonuses and aim to use variable remuneration to increase the motivation of managers and thus their commitment to the company and the achievement of company goals through extrinsic incentives.

The instrument of variable remuneration is also used for commercial employees, but often in the form of special payments (Slimka et al., 2018). According to a 2015 study by the Federal Statistical Office in Wiesbaden, more than three-quarters of all employees received a special payment at least once in the reporting year 2010. The average sum of the annual special payments amounted to more than 3,600 euros. This corresponded to a share in gross annual earnings of around $8 \%$. On average, an employee thus received about one additional month's salary as a special payment (Weber \& Beck, 2015).

Senior executives? Commercial employees? Project managers? None of the empirical studies considered so far gives an approach whether at all - and if so, to what extent project managers of variable remuneration systems participate. At first it seems logical and conceivable, even desirable, to allow project managers to participate in the success of their projects. After all, a project manager must not only have the appropriate technical expertise and the ability to manage staff, but must also contribute a large amount of enthusiasm for "his" project. He must have the gift of passing this enthusiasm on to his project team members, motivating the team members to achieve the common goal and at the same time demanding maximum performance from his project team members. Project managers contribute significantly to the success of the company. Jakoby describes the tasks of a project manager as follows; "Project managers therefore require a special degree of psychological prerequisites which give them the necessary drive to master the tasks" (Jakoby, 2015) Jakoby further describes that above all ambition, perseverance, a sense of responsibility and "a healthy degree of self-confidence" should be elementary personality traits of a project manager (Jakoby, 2015). The participation of the project leader in the success of the project, or the prospect of such participation, should be seen as an incentive to increase the motivation and commitment of the project leader to his project. This raises two essential questions for further research:

- How is the success of the project measured?

- What is the variable remuneration component based on?

Bredillet analyses in 2010 in the Project Management Journal published article > Blowing hot and cold on project management $<$ that in some industries up to $30 \%$ of all companies work according to project management methods (Bredillet, 2010). In the author's view, this seems to be an underestimated figure, at least for the German construction industry and ancillary construction industry. The author assumes that in the German construction industry the share of project business must be estimated much higher, probably even close to $100 \%$, due to the respective individual specifics of a construction site.

On the one hand, from the point of view of the project managers, individual participation in the respective project success would only be fair to the other managers. After all, each project manager "fights" in his project(s) with commitment and individual responsibility for the best possible project result and thus for the greatest possible contribution to the company's success. In this sense, a project manager justifiably feels that he or she is a 
significant part of the entire company and could certainly participate in a bonus scheme at company level, but without direct project-specific motivation.

On the other hand, many authors describe the counterproductive effect of variable compensation on the motivation of employees with complex tasks (Eyer \& Haussmann, 2014; Frey \& Osterloh, 2000; Holmstrom \& Milgrom, 2012; Rodorff, 2013; Tommasi \& Weinschelbaum, 2007). The tasks of a project manager can certainly be classified as highly complex. Deci, Ryan and Koestner carried out a number of experiments in 1998/1999 and analyse comprehensive meta-analyses (Deci et al., 1999).

Like Fey and Osterloh, they describe a so-called >displacement effect $<$ in terms of the overall economic pursuit of objectives compared with non-premium targets (Frey \& Osterloh, 2000). This displacement effect is achieved by reducing the overall complexity of all target facets to the bonus-relevant targets. Frey and Osterloh describe the term displacement effect as follows: "The displacement effect establishes a systematic relationship between extrinsic and intrinsic motivation. An external (extrinsic) intervention has the effect of undermining or even displacing an activity that is undertaken (intrinsically) out of joy in oneself" (Frey \& Osterloh, 2000).

On the one hand, project managers could find themselves deprived of their individual creativity (patronized) by the specifications of a variable remuneration model, and on the other hand, they could lose sight of the needs of the entire company if they focus too much on their own project (with too much target focus). Especially with regard to internal scarce resources, project managers could be hostile to each other within a company and in extreme cases damage the spirit of the company. In exposed cases, "cannibalization" can occur within a company. If a project manager has the choice of being able to freely dispose of all internal personnel resources of a company, he will initially tend to equip his project team with the best of the best in order to have a supposedly easy job of solving the project task. Similar to the choice of football teams in the schoolyard, inexperienced young talents are left behind and are not elected to the team. This leads on the one hand to an enormous de-motivation of young talents, and on the other hand to a medium-term lack of top talent. In the worst case, the company will lose its attractiveness and the good potential junior staff will leave the company sooner or later due to a lack of development opportunities.

\section{b) Performance incentives to increase motivation:}

Motivation and incentives in project management inevitably affect a distinction between extrinsic and intrinsic motivation. A clear distinction is controversial in professional circles to date. Mühlenhof poses the question "whether a scientific survey of inner processes, some of which are conscious and some of which are unconscious, is at all possible" (Mühlenhof, 2018). The aim of this scientific paper is to create the basis for implementing a variable remuneration system and thus a quasi reward and incentive system. For this reason, the author nevertheless considers it purposeful to make a sequential differentiation between extrinsic and intrinsic motivation, without, however, claiming for this publication that all scientific views of this complex subject area are complete.

According to Maier, intrinsic motivation is understood as a state "in which action is taken because of an inner stimulus that lies in the activity itself, e.g. in the feeling of the flow experience" (Maier \& Kirchgeorg, 2018). Following Maier, the author can describe the intrinsic motivation from his own experience with three examples.

First, the introductory example of this publication, the formwork-side project management of the Leibis/Lichte dam. A civil engineer can hardly feel more pride in managing such an exposed and meaningful project, at his own discretion, as a motivating impetus.

$>$ Another cluster of intrinsic motivation lies in writing scientific publications, such as this paper. No one forces the author to do so, and yet he voluntarily submits to these challenges because he sees a purpose behind it.

$>$ A third aspect lies in sport; the author tries to run a marathon every year. It is much easier to survive the pain on the distance of about $42 \mathrm{~km}$, if you only want to get through it by yourself. You are not forced to do this either - you act voluntarily and motivate yourself to persevere (without asking about the sense of running a marathon, by the way). 
Depending on one's physical and mental condition, one experiences the flow experience led by Maier as a state of being in a tunnel, shielded from the sensory perception of the outside world, highly concentrated, preoccupied only with oneself and one's thoughts (Maier, 2018).

In 1993 Csikszentmihalyi \& Schiefele describe the flow experience as a "feeling of being completely absorbed in an activity" (Csikszentmihalyi \& Schiefele, 1993) in the context of a group of artists (painters and sculptors) who created their sculptures with "considerable enthusiasm" (Csikszentmihalyi \& Schiefele, 1993) on a daily basis, remarkably independent of their monetary remuneration. According to the author's assessment, which cannot be empirically proven, many of the current publications on intrinsically motivated behavior are based on Deci and Ryan. Both tried to describe approaches to motivating learning in a pedagogical context (Deci \& Ryan, 1993; Deci et al., 1999; Klusmann, Trautwein, \& Lüdtke, 2005).

In addition to Maslow's well-known pyramid of needs, a much-admired explanatory model illustrates the motivating influences on employees, Frederick Herzberg's >two-factor theory<. The two-factor theory describes which external factors trigger satisfaction or dissatisfaction among employees. In 1968, Herzberg focused his research on the relevant question: > How do you motivate employees< (Herzberg, 1968), describing it in the words: "How do I get an employee to do what I want? (Herzberg, 1968) and thus somewhat drastically transfers his $>$ two-factor theory $<$ to economics. The two main factors, the so-called $>$ hygiene factors $<$ and the so-called $>$ motivators $<$ are briefly presented in the following table.

Table 1. Two-factor theory, main factors

\begin{tabular}{|l|l|}
\hline Hygiene factors & Motivators \\
\hline Remuneration & Work performance \\
\hline Working conditions & Responsibility \\
\hline Job security & Positive development \\
\hline Atmosphere & Recognition \\
\hline Quality of leadership & Success \\
\hline
\end{tabular}

Source: Herzberg (1968).

The decisive lever of Herzberg's theory is that the hygiene factors must be fulfilled as an elementary basic requirement; if they are not fulfilled, they immediately trigger dissatisfaction in the employee. Changes in these hygiene factors generate short-term satisfaction among employees. Positive changes in motivators, on the other hand, create long-term satisfaction among employees.

In 2010, Kahneman and Deaton also came to the corresponding statement > High income improves evaluation of life but not emotional wellbeing< (Kahneman \& Deaton, 2010) in the course of their extensive empirical research and thus support the thesis that hygiene factors must be fulfilled as an elementary basic requirement and that above a certain income threshold, an increase in income only leads to a short-term improvement in well-being. Based on the initial example of the candidate at the Leibis/Lichte Dam, the motivators "work performance" (the wall is up), "responsibility" (for the one-off project), "positive development" (the candidate's career development after the project is completed), "recognition" (professionally, among friends, privately) and finally the "success" of the project can be analyzed as long-term positive factors for satisfaction and well-being.

The concept of >extrinsic motivation< refers to a state in which action is taken on the basis of the expected consequences of the activities (e.g. positive staff appraisal, salary increase etc.) (Maier, 2015). Edelmann states that extrinsic motivations are "among the rewards" (Edelmann, 2003). Frey and Osterloh subsume extrinsic motivation with economic incentives and conclude from this that extrinsic incentives could overlap the intrinsic motivations in a kind of >displacement effect< (Frey \& Osterloh, 1997). The author does not entirely agree with this opposing argumentation, or at least it can be stated that within limits a potentiation of motivation occurs, namely precisely when incentives run parallel and are thereby stimulated to take adequate action.

Project management is more than carrying out self-contained tasks and leading groups. Project management is emotion, project leadership is the awakening of enthusiasm, team building, integration and meaning. Project managers have to perform the feat of motivating seconded employees for the common project goal, making them 
understand the meaning of the task, constituting them into an efficient project team and, in addition, giving the project members a "home" (Swonke \& Schneider, 2013). The following chapter deals with the mechanisms of identification in project management.

\section{c) Potentials of meaningful activities:}

For the temporary duration of a project, heterogeneous types of people come together, who together have to face diverging internal and external demands. The project team members have to be transformed into a goal-oriented working team in a short time. Particularly in matrix organisations, these specifics in the quality of knowledge communication and the need for compromises become eminent due to the need for coordination with the sending departments (Wohlwender, 2014). A project team consists of different people, with different backgrounds, different pasts and different qualifications, all of whom together form the project organisation. While a project team has to be formed anew at each project start, all team members develop into independent individuals in the course of their lives.

According to McCrae and Costa, the different personalities can be divided into five different personality types that do not clearly overlap. McCare and colleagues name the following descriptive characteristics in 1987 (McCrae \& Paul T. Costa, 1987).

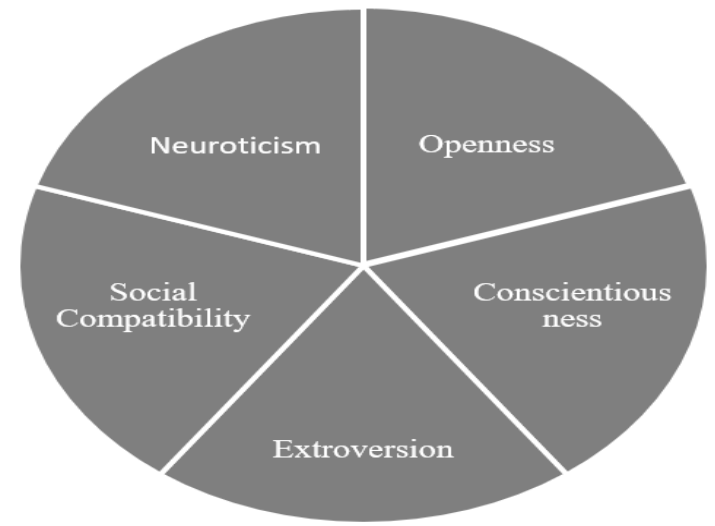

Figure 2. Personality types according to McCrae and Costa,

Source: own representation.

In principle, this subdivision applies to all personality types, but it is particularly relevant due to the short formation phase of a project team. In the early phase of project team composition, different expectations and needs collide with different team members and their different personality types.

Mohan and Ahlemann analyse five basic needs in terms of sociological and psychological theories, referring to > Murry's needs theory< and the > Theory of planned behaviour< (Ajzen, 1991; Mohan \& Ahlemann, 2013; Murray, 1938). These needs and their associated behavioral characteristics are listed in the overview below and have a significant impact on the team building process and the speed with which a new team is ready to take joint responsibility for the project.

Table 2. Needs theory; theory of planned behaviour

\begin{tabular}{|l|l|}
\hline \multicolumn{1}{|c|}{ Need for } & \multicolumn{1}{c|}{ Description of the behavioural characteristics } \\
\hline Performance & $\begin{array}{l}\text { Search for success, positive feedback, striving for best performance, result-orientation, } \\
\text { efficiency and difficult tasks are recognised as challenges. }\end{array}$ \\
\hline Affiliation & Striving for acceptance, personal relationships, avoiding conflicts. \\
\hline Power & Striving for leadership, assumption of group responsibility, status orientation. \\
\hline Understanding & Striving for knowledge, making considered decisions, evaluating facts to minimise risk. \\
\hline Guilt defense & $\begin{array}{l}\text { Defensive behaviour, not capable of criticism, no acceptance of responsibility in case of } \\
\text { mistakes. }\end{array}$ \\
\hline
\end{tabular}

Source: Ajzen, 1991; Mohan \& Ahlemann, 2013; Murray, 1938. 
According to Tuckmann, the phases of this team-building process are described in five subsequent phases (Tuckmann, 1965).

Table 3. Team building process according to Tuckmann

\begin{tabular}{|ll|l|}
\hline \multicolumn{2}{|c|}{ Team building phase } & \multicolumn{1}{c|}{ Impact on the team and its functioning } \\
\hline 1) & Formation & a new team is put together \\
\hline 2) & Storming & an initial pseudo-team is created, first bonds grow \\
\hline 3$)$ & Standardisation & the team lives with its rules, a team with potential is created \\
\hline 4$)$ & Execution & the team authenticates itself with the project, with the project goals and with itself \\
\hline 5) & Fusion & $\begin{array}{l}\text { all project tasks are carried out jointly by the highly efficient team, differentiated according } \\
\text { to individual strengths }\end{array}$ \\
\hline
\end{tabular}

Source: Tuckmann (1965).

Tuckmann describes the phases of team building and the associated increase in efficiency as a curve. However, the experience of the twosome suggests that team performance must develop more linearly in relation to team effectiveness in order to be able to act early in the project process. The project manager has a significant responsibility for accelerating the team building process. Both views are superimposed on the following diagram (Zwerenz, 2019).

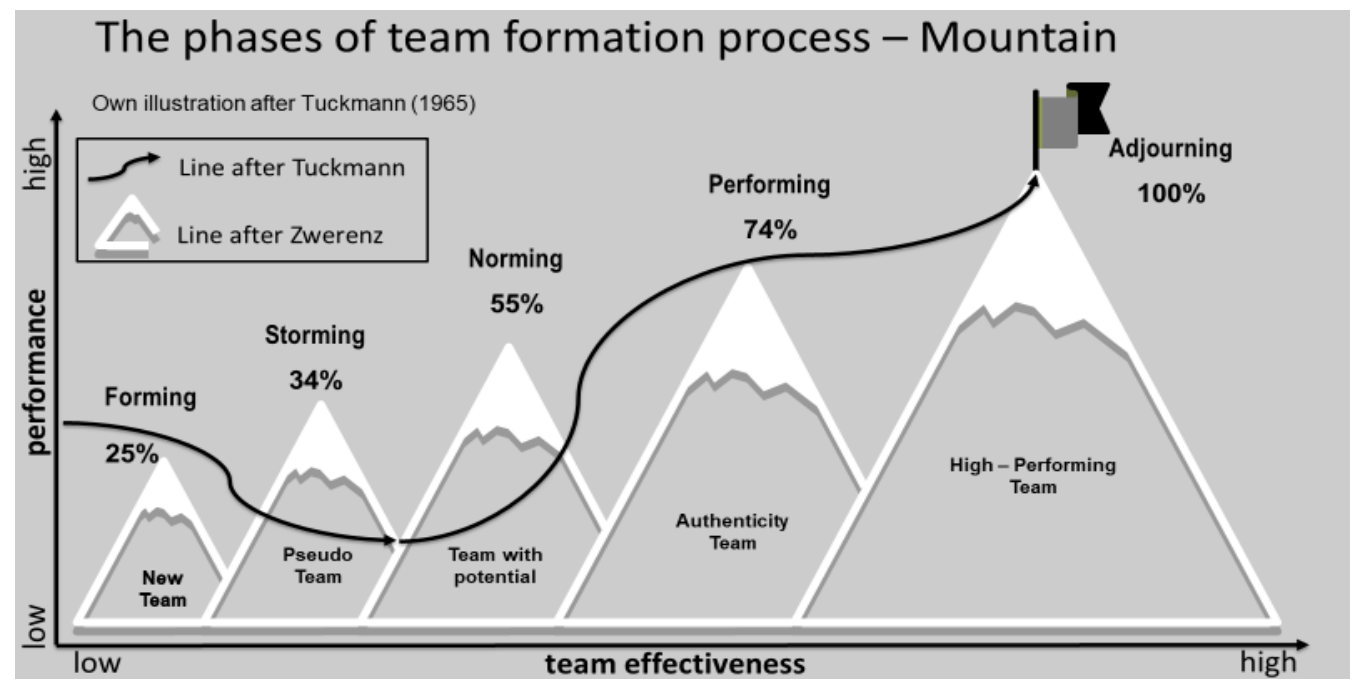

Figure 3. The phases of the team building process - Berg

Source: illustration after Tuckmann, adapted by Zwerenz (Tuckmann, 1965; Zwerenz, 2019)

From the extracted knowledge about personality individuals and the different needs of people, the compelling question arises for the project manager during the team building process;

- How can employees be convinced of the project and the project management process even more quickly in order to grow together into a high-performance team at an earlier stage?

Mohan and Ahlemann name the factors > benefit<, > social influence $<$, >self-perception $<$ and >organisational characteristic $<$ as prerequisites for the acceptance of project management (Mohan \& Ahlemann, 2013). These factors are presented below in the context of team building (Zwerenz, 2019). 


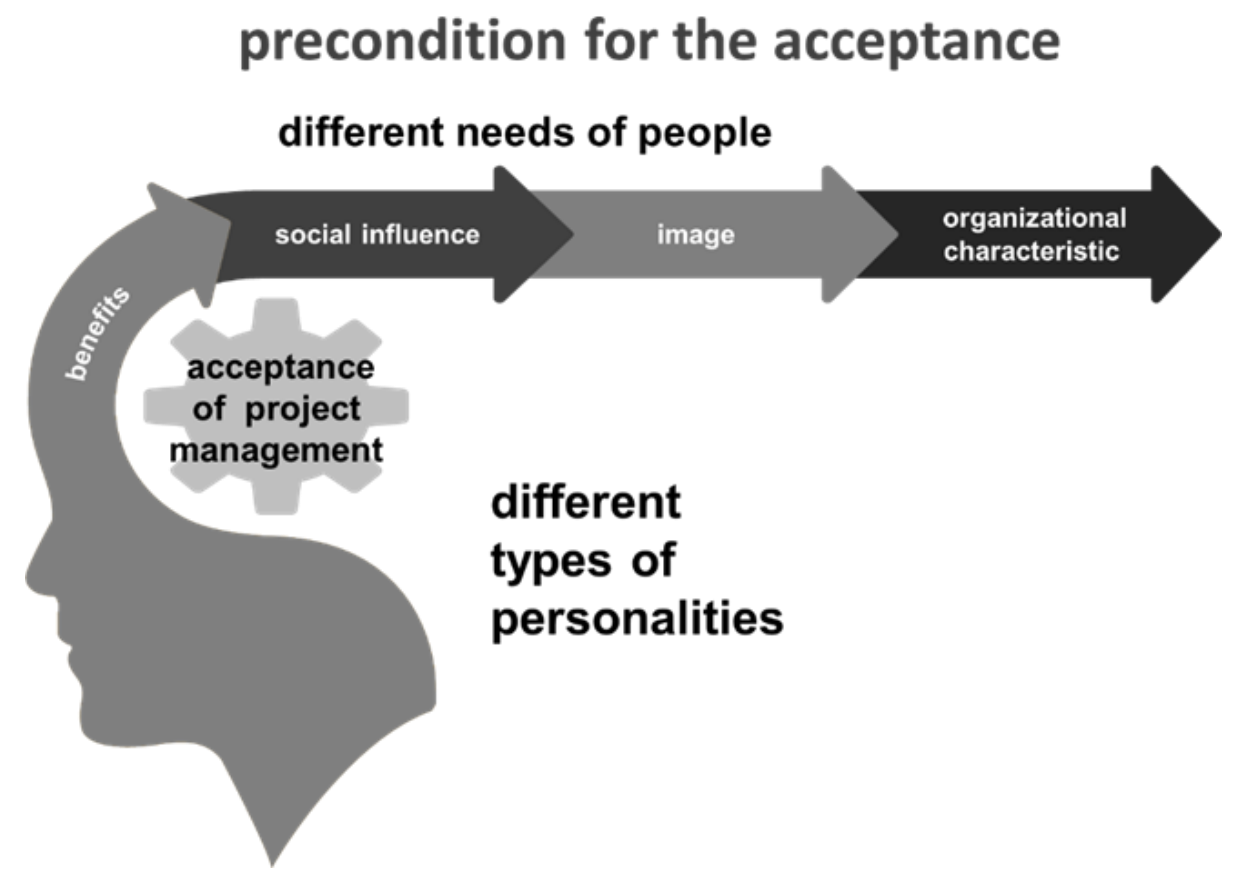

Figure 4. Acceptance in project management

Source: adaptation by Zwerenz (Mohan \& Ahlemann, 2013; Zwerenz, 2019)

From a psychological point of view, the acceptance model explains the way in which the acceptance of team members for project management in principle arises, but it still does not explain the most effective way to achieve this acceptance. Therefore, the following additional questions are derived from previous considerations;

- Which organisational behaviour model can be used to achieve acceptance for a project?

- Can marketing tools help to increase acceptance?

- Which values in project management help to build acceptance?

Project management is characterised by the fact that different employees from different departments, from different branches, from different groups have to be recruited for each project. The motives of the employees provided by the departments can be completely different, also the experience and skills of the employees will be completely different. In order to grow together in the shortest possible time into a competent, efficient, homogeneous group (within the team), the potential project team needs values. The values are needed so that the team members can identify themselves as part of the project team. In 2012 Borgert describes values as: "guidelines by which we orient our thinking and acting as individuals and as a team" (Borgert, 2012), and Borgert continues to write: "they are an integral part of a project culture" (Borgert, 2012). From Borgert's point of view, values can be communicated to the team in every phase of the project, but of course the formation phase at the beginning of the project is a particularly good time to define these values. For the development of the value hierarchy within the project culture, Borgert describes two questions that should be worked on together as a team (Borgert, 2012):

- $\quad$ "What is important to us?" (Borgert, 2012)

- "What do we think about ourselves as a team?" (Borgert, 2012)

The author would tend to extend these questions to three essential issues.

- What is the project goal and how does the project goal integrate into the company's values?

- Does the project team see the sense behind the project goal?

- Does the sense of the project correspond to the values of individual team members? 
Here, too, the author has to find out in his daily practice that project goals make absolute sense from a company's point of view, but do not necessarily have to correspond to the personal values of the individual project members. In the German construction industry, for example, it is quite possible for a company to carry out a prestige project at economically inappropriate conditions for reasons of external marketing. A negative economic project result is calculated in advance for many strategic reasons. The core team is informed of the planned shortfall in the sense of open project communication. However, this approach leads to frustration, lack of understanding and even demotivation of the entire team. Although the company is fully aware of this strategic step, the meaning of this decision is difficult to communicate to the team members.

The initial example of the Leibis/Lichte dam shows that it is all the more important to communicate the meaning of the project to the project team in addition to the project objective. Barmeyer describes the values (the meaning): "historical, cultural-relative, desirable guidelines and behaviour-controlling decision-making rules of a group or society" (Barmeyer, 2000). He further describes that values (the meaning) can relate to objects and conditions, but also to the workplace, leisure time or the shared values of a partnership. The value system facilitates orientation in the environment for the individual and organises interaction with other people (Barmeyer, 2000). The project members, who see their project as a production cell and as their own value space, can thus be seen as a community of values embedded in the entire company. That this can work and that the former project team members still share and cultivate the values of the joint >Leibis/Lichte dam project after many years is evident from the annual $>$ Leibis meeting $<$ described above.

However, it should be noted that other aspects, such as the sustainability of the project objective, must be embedded in the corporate context and must not be counterproductive to the corporate objectives. The sustainability of the project is described as a business value, "which has established itself through its plausibility as a model for problem solving" (Stehr, Dziatzko, \& Struve, 2019). The task of living the principle of sustainability in his project and communicating it to his team is that of the project leader as a manager. However, the views on what is called sustainability can vary greatly depending on the point of view of different people. From the employee's point of view, sustainability, whatever it may be, is often understood as minimising the individual carbon footprint. From the entrepreneur's point of view, the question of sustainability is certainly answered with economic survival and growth of his company. Stehr quoted Friedmann on sustainability and performance: "There is one, and only one, social responsibility of business to use its resources and carry out activities to increase its profits as long as it plays by the rules of the game" (Stehr et al., 2019).

Pryor describes this neo-liberal view of corporate social responsibility and assumes once again, up to the 20th century, that the acquisition of corporate social responsibility can very well be in the direct interest of our corporate activities. These two aspects are not contradictory (Pryor, 2010), which means that for project management and thus for the project leader, the project manager must represent the corporate values both internally and externally and at the same time reconcile the project objective with the requirements of social sustainability and its meaning.

An essential leadership role of project management is to resolve this apparent conflict of values (conflict of meaning). If the requirements for value compensation are met, the value conflict between all project participants is balanced and skillfully communicated, a high performance project team can be formed into a high performance team. The earlier this is done in the project execution, the better for the formation of the team and the further course of the project. For the project manager, however, the task of conveying values does not end until the project is completed and the final project meeting is held. The aspects of motivation for projects, identification in project management and values in project management to consolidate a brand identity concept for project management were scientifically described by Zwerenz in 2019 (Zwerenz, 2019).

\section{Evaluation intervals of a variable remuneration}

The evaluation intervals of the variable remuneration should be carried out promptly in accordance with the deficiency described by Klausing in the study > Salary and Career in Project Management 2017< (Klausing, Scheurer, Christoph, Wald, \& Gröber, 2017) in order to effectively counteract a lack of coincidence of performance and reward. A temporal coincidence of high commitment of the project manager and extrinsic reward 
by the employer will result in a stronger, "more tangible" - intrinsic commitment of the project manager to his goals and the achievement of the same. This coupling additionally increases the intrinsic motivation of the project manager.

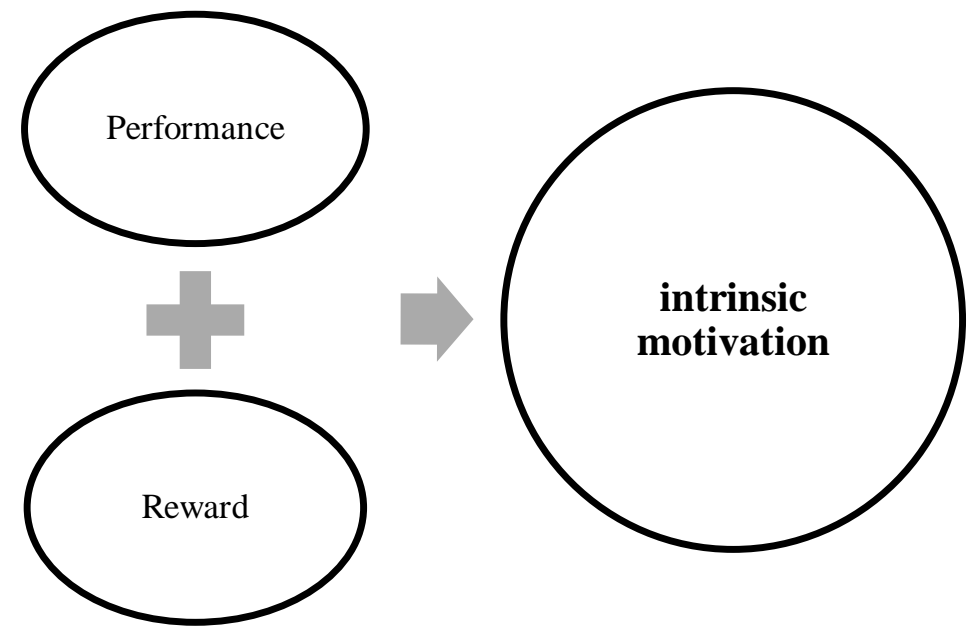

Figure 5. Relationship between performance/rewards and intrinsic motivation

\section{Conclusions and recommendations}

\section{a) Testing the hypothesis}

At the beginning of the article the research gap was described and the corresponding theses were derived from it.

T 1) Motivated project managers have a decisive influence on the success of the project.

T 2) The motivation of project managers can be increased by extrinsic incentives.

T 3) The presentation of the meaning of the project is elementary for the formation of the project team and is a core task of a project manager.

T 5) The people working together in a project must be inspired for the project in order to grow together to form a project team and recognize its purpose.

T 6) Employees who identify themselves with a project and the team are prepared to provide the highest personal service to the project.

The hypothesis was derived from the theses and evaluated on the basis of the research results. Project managers do not carry out the causal work for the project on their own, but rely on the support of their project team and its smooth and creative solution orientation. The work in a project team could be ordered by sending personnel. However, belonging to a project team follows the same mechanisms as the desire to belong to a famous football team or another successful association. In order to awaken this desire to belong among the potential employees of a project, the challenge remains for the project manager to build up a sophisticated image of his project that creates identity and meaning. The initial example $>$ Leibis/Lichte dam $<$ was used to describe the desire to belong to a group, even after completion of the project, in the growing number of participants at the annual >Leibis meeting <. In addition to a solid technical implementation, the way the project is carried out, the "sense" of the project and stakeholder management are obviously of particular importance. Radtke uses four constitutive characteristics to describe a brand; >reciprocity< (reciprocity), >individuality< (distinctiveness), >continuity< (steadiness) and >consistency< (cohesion) (Radtke, 2014). Our own quantitative studies and the findings gained in the previous chapters allow us to state that the hypothesis put forward can be regarded as confirmed. 
Hypothesis confirmed. A project has to establish itself as a useful task in the company in order to facilitate the identification of the employees with the project and the team building. The project manager has to take over the function of the sense ambassador of his project within the company and outside the company.

\section{b) Other new scientific findings}

As a result of this research, the following new scientific findings can be made available to the professional community.

Marginal utility of variable remuneration systems:

$>$ A moderate increase in the income of project managers has only a minor effect on the motivation and behavioral changes of a project manager, whereas countercyclical (project-dependent) variable remuneration components can have a motivating effect on the project manager.

> Variable compensation systems can have counterproductive effects. Previously established variable remuneration systems are not suitable for the professional group of project managers due to the risk involved.

Performance incentives to increase motivation:

$>$ A distinction between extrinsic and intrinsic motivation makes sense sequentially, if not without overlap. Project managers must be able to motivate their team and themselves and explain the purpose of the project to them.

Potentials of meaningful activities:

$>$ Different personality types come together in project teams and must be formed into an efficient project team as quickly as possible by the project manager. A prerequisite for rapid team formation is identification with the project goal and acceptance of the project.

$>$ The formation of acceptance in project management can be achieved through values, sustainability and SINN. The project manager's task is to convey meaning.

\section{Summary}

In this article the tension between income, recognition and well-being was discussed. Karl Marx's views on the topic of money as an arbitrary, motivelessly interchangeable medium and the diminishing marginal utility described in the Gossensche Laws were transformed into a conflict of goals between careers in project management and a fulfilled private life. The area of conflict described can be well explained with the model of Kahneman and Deaton (Kahneman \& Deaton, 2010) for the two ends of the income scale (top earners and employees with minimum income).

Top management can afford to be "unreachable" and in many cases is motivated by variable remuneration, which is usually based on global company key figures and not necessarily directly on individual performance.

$>$ The "normal conveyor belt worker" works in specified working hours and defined work processes. He or she does not usually have to be available outside of working hours and in some cases receives a performancerelated, individual quantity bonus for exceeding the norm.

$>$ And in what way do the project managers participate? The professional group responsible for which of the "million-dollar" projects responsible for planning, controlling and monitoring, which are expected to take on a lot of responsibility for projects, have not yet participated directly in their individual commitment. This urgently requires a change.

Furthermore, the dependencies of meaningfulness, recognition and income were derived from the literature and the factors influencing personal well-being were presented. Finally, the extract of these research results forms the basis of a possible basic configuration of a motivating remuneration system as an incentive system in project management. A differentiation between intrinsic and extrinsic motivation was made without having completely worked through all facets of the scientific literature on this difficult topic. At least to some extent, this distinction 
was needed in order to be able to accompany the scientific discourse on a motivating remuneration model in a differentiated way. The finding that a temporal coupling of high commitment of your project leader and extrinsic reward of the employer leads to a stronger intrinsic connection of the project leader to his goals confirms this approach.

\section{Further research needs}

High income improves evaluation of life but not emotional well-being (Kahneman \& Deaton, 2010). In 2010, Kahneman and Deaton's research provided fundamental statements on the relationship between income and emotional well-being, as well as the dependent consequences of salary changes on well-being in the US. For Germany as a research location, the statements still tend to be usable. However, due to different life circumstances and other life goals of younger generations, the author believes that an updated and differentiated consideration based on Kahneman and Deaton's studies is necessary.

Furthermore, additional factors of the performance evaluation of a project manager have to be explored and the diagnosed parameters have to be transformed into measurable variables.

Funding: self-funded.

Author contribution: conceptualization, Dirk Zwerenz; data curation, Dirk Zwerenz; formal analysis, Dirk Zwerenz; funding acquisition, Dirk Zwerenz; investigation, Dirk Zwerenz; methodology, Dirk Zwerenz; project administration, Dirk Zwerenz; resources, Dirk Zwerenz; software, Dirk Zwerenz; supervision, Dirk Zwerenz; validation, Dirk Zwerenz; visualization, Dirk Zwerenz; writing - original draft, Dirk Zwerenz; writing - review \& editing, Dirk Zwerenz.

\section{References}

1. Ariely, D., Loewenstein, G., \& Prelec, D. (2006). Tom Sawyer and the construction of value. Journal of Economic Behavior and Organization, 60(1), 1-10. https://doi.org/10.1016/j.jebo.2004.10.003

2. Ajzen, I. (1991). The theory of planned behavior. Organizational Behavior and Human Decision Processes 50(2), 50(2), 179-211. doi: 10.1016/0749-5978(91)90020-T.

3. Amelung, V. E. (2019). Vergütungssystem. In Gabler Wirtschaftslexikon. Available at: https://wirtschaftslexikon.gabler.de/definition/verguetungssystem-51773/version-274926.

4. Atkinson, R., Crawford, L., \& Ward, S. (2006). Fundamental uncertainties in projects and the scope of project management. International Journal of Project Management, 24(8), 687-698. Available at: https://doi.org/10.1016/j.ijproman.2006.09.011.

5. Bahnmüller, R. (2001). Stabilität und Wandel der Entlohnungsformen.(Entgeltsysteme und Entgeltpolitik in der Metallindustrie, in der Textil-und Bekleidungsindustrie und im Bankgewerbe). München: Rainer Hampp Verlag. Available at: http://infinity.wecabrio.com/3879886164-stabilitat-und-wandel-derentlohnungsformen-entge.pdf.

6. Barmeyer, C. I. (2000). Interkulturelles Management und Lernstile: Studierende und Führungskräfte in Frankreich, Deutschland und Quebec. Available at: https://d-nb.info/958394970/04.

7. Becker, G. S. . (1993). Nobel Lecture: The Economic Way of Looking at Behavior Authors ( s ): Gary S. Becker. Journal of Political Economy, 101(3), 385-409. Available at: http://www.jstor.org/stable/2138769.

8. Bemmé, S.-O. (2011). Erfolgsfaktor Mensch im Kultur-Projektmanagement. In Kultur-Projektmanagement. doi: https://doi.org/10.1007/978-3-531-92755-8.

9. Bender, G. (1997). Lohnarbeit zwischen Autonomie und Zwang: Neue Entlohnungsformen als Element veränderter Leistungspolitik. Campus Verlag. doi: https://doi.org/10.1007/s11577-003-0088-3.

10. Blinder, A. S. (1990). Paying for productivity: A look at the evidence. Washington, D.C.: Brookings Institution Press. Available at: https://www.brookings.edu/book/paying-for-productivity/.

11. Borgert, S. (2012). Go Live: Interventionen des holistischen Projektmanagements. In Holistisches Projektmanagement. doi:https://doi.org/10.1007/978-3-642-25702-5.

12. Bredillet, C. N. (2010). Blowing hot and cold on project management. Project Management Journal, 41(3), 
SocioEconomic Challenges, Volume 4, Issue 4, 2020

ISSN (print) - 2520-6621, ISSN (online) - 2520-6214

4-20. doi: https://doi.org/10.1002/pmj.20179.

13. Brodbeck, F., \& Guillaume, Y. (2018). Umgang mit Informationen und Meinungsbildung in Projekten. In Angewandte Psychologie für das Projektmanagement - ein Praxisbuch für die erfolgreiche Projektleitung (pp. 43-62). doi: https://doi.org/10.1007/978-3-642-19920-2.

14. Csikszentmihalyi, M., \& Schiefele, U. (1993). Die Qualität des Erlebens und der Prozess des Lernens. Zeitschrift Für Pädagogik, 2(3), 207-222. Available at: https://publishup.uni-potsdam.de/opus4ubp/frontdoor/deliver/index/docId/3177/file/schiefele1993 39.pdf.

15. Deci, E. L., \& Ryan, R. M. (1993). Die Selbstbestimmungstheorie der Motivation und ihre Bedeutung für die Pädagogik. Zeitschrift Für Pädagogik, 39, 223-238. doi: https://doi.org/10.1017/CBO9781107415324.004.

16. Deci, E. L., Ryan, R. M., \& Koestner, R. (1999). A meta-analytic review of experiments examining the effects of extrinsic rewards on intrinsic motivation. Psychological Bulletin, Vol. 125, pp. 627-668. doi: https://doi.org/10.1037/0033-2909.125.6.627.

17. Dressler, M. (2000). Variable Anreizsysteme motivieren. Personalwirtschaft, Sonderheft, 9, 40-46.

18. Eckardstein, D., \& Janes, A. (1995). Neue Wege der Lohnfindung für die Industrie. Wien: Manz Wirtschaft.

19. Edelmann, W. (2003). Intrinsische und extrinsische Motivation. Grundschule, Vol. 35, pp. 30-32. https://doi.org/10.1016/B978-3-437-23274-9.00005-8.

20. Eyer, E., \& Haussmann, T. (2014). Zielvereinbarung und variable Vergütung. In Igarss 2014. https://doi.org/10.1007/s13398-014-0173-7.2.

21. Falk, A., \& Szech, N. (2013). Morals and markets. Science, 340(6133), 707-711. https://doi.org/10.1126/science.1231566.

22. Fließ, S. (2006). Vertriebsmanagement. In Markt- und Produktmanagement (pp. 322-364). https://doi.org/10.1007/978-3-8349-9050-1_1.

23. Frankl, V. E. (2010). ... trotzdem Ja zum Leben sagen: Ein Psychologe erlebt das Konzentrationslager. Available https://books.google.de/books?hl=de\&lr=\&id=461H0NMFnqsC\&oi=fnd\&pg=PT2\&dq=viktor+frankl\&ots= KNdh0MwdOk\&sig=Uk28t2FLS Qm3--lWwVkcrMAmnk\#v=onepage\&q=viktor frankl\&f=false.

24. Frey, B. S., \& Osterloh, M. (1997). Sanktionen oder Seelenmassage? Motivationale Grundlagen der Unternehmensführung. Die Betriebswirtschaft, 57(4), 307-321. Available at: https://www.bsfrey.ch/articles/C_289_1997.pdf.

25. Frey, B. S., \& Osterloh, M. (2000). Pay for Performance Pay for Performance - Immer empfehlenswert? Zeitschrift Für Führung Und Organisation, 69(2), 64-69. doi: https://doi.org/0803973233

26. Frey, B. S., \& Osterloh, M. (2002). Motivation - der zwiespältige Produktionsfaktor. In Managing Motivation (p. S. 20-42). Available at: https://www.springer.com/de/book/9783409216319.

27. Goldenstein, J., Hunoldt, M., \& Walgenbach, P. (2018). Empirisch-quantitative Forschung. In Wissenschaftliche(s) Arbeiten in den Wirtschaftswissenschaften (pp. 107-133). doi: https://doi.org/10.1007/978-3-658-20345-0.

28. Grösser, S. N. (2012). Dynamische Komplexität ist die große Herausforderung für das Management: Mit Business Dynamics werden Controller zu Meistern des Komplexitätsmanagements. CFO Aktuell, 6(2), 6772. doi: https://doi.org/10.1017/CBO9781107415324.004.

29. Haun, M. (2016). Cognitive Organisation. doi: https://doi.org/10.1007/978-3-662-52952-2

30. Haun, V. C. (2019). Handbuch Karriere und Laufbahnmanagement (Springer R). Berlin, Heidelberg: Prof. Dr. Simone Kauffeld, Dr. Daniel Spurk. https://www.springer.com/de/book/9783662487495.

31. Hauschildt, J. (1999). Widerstand gegen Innovationen - destruktiv oder konstruktiv? Innovation Und Absatz, (September), 1-22. doi: https://doi.org/10.1007/978-3-322-89809-8_1

32. Hertel, G., \& Lauer, L. (2012). Führung auf Distanz und E-Leadership - die Zukunft der Führung? In Die Zukunft der Führung (pp. 103-118). doi: https://doi.org/10.1007/978-3-642-31052-2

33. Herzberg, F. (1968). One more time: how do you motivate employees? Harvard Business Review, 46(1), 53-62. Available at: https://hbr.org/2003/01/one-more-time-how-do-you-motivate-employees.

34. Heywood, J. S., Siebert, W. S., \& Wei, X. (1997). Payment by Results Systems: British Evidence. British Journal of Industrial Relations, 35(1). https://doi.org/https://doi.org/10.1111/1467-8543.00038

35. Holmstrom, B., \& Milgrom, P. (2012). Multitask principal???agent analyses: Incentive contracts, asset ownership, 
and job design. In The Economic Nature of the Firm: A Reader, Third Edition (pp. 232-244). doi: https://doi.org/10.1017/CBO9780511817410.018

36. Jakoby, W. (2015). Projektmanagement für Ingenieure. doi: https://doi.org/10.1007/978-3-658-02608-0.

37. Jerger, J. (1993). Das St. Petersburg-Paradoxon. WiSt - Wirtschaftswissenschaftliches Studium, 8, 407-410. Available at: https://epub.uni-regensburg.de/9407/

38. Kahneman, D., \& Deaton, A. (2010). High income improves evaluation of life but not emotional well-being. Proceedings of the National Academy of Sciences, 107(38), 16489-16493., 107(38), 16489-16493. https://doi.org/https://doi.org/10.1073/pnas.1011492107

39. Kampkötter, P. (2014). Performance Appraisals and Job Satisfaction (No. 672). Available at: http://hdl.handle.net/10419/99955.

40. Kampkötter, P., Mohrenweiser, J., Sliwka, D., Steffes, S., \& Wolter, S. (2015). Measuring the use of human resources practices and employee attitudes: The Linked Personnel Panel (No. 35/2015). Available at: http://hdl.handle.net/10419/126534.

41. Kampkötter, P., \& Sliwka, D. (2011). Differentiation and Performance: An Empirical Investigation on the Incentive Effects of Bonus Plans (No. 6070). Available at: http://hdl.handle.net/10419/58862

42. Kampkötter, P., Sliwka, D., Butschek, S., Petters, L., \& Grunau, P. (n.d.). Monitor, Variable Vergütungssysteme (p. 28). p. 28. Available at: https://www.inqa.de/DE/Angebote/Publikationen/monitor-variableverguetungssysteme.html

43. Keynes, J. M. (1937). The General Theory of Employment. The Quarterly Journal of Economics. doi: https://doi.org/10.2307/1882087

44. Kieser, H.-P. (2016). Variable Vergütung im Vertrieb, 10 Bausteine für eine motivierende Entlohnung im Außenund Innendienst. In Variable Vergütung im Vertrieb. doi: https://doi.org/10.1007/978-3-658-07144-8

45. Klausing, H. P. D., Scheurer, S. P. D., Christoph, S., Wald, A. P. D., \& Gröber, M. (2017). Gehalt und Karriere im Projektmanagement 2017. Available at: https://www.projektmagazin.de/artikel/gehalt-und-karriere-improjektmanagement_1130075

46. Klusmann, U., Trautwein, U., \& Lüdtke, O. (2005). Intrinsische und extrinsische Lebensziele: Rehabilität und Validität einer deutschen Fassung des Aspirations Index. Diagnostica, 51(1), 40-51. doi: https://doi.org/10.1026/0012-1924.51.1.40

47. Kohn, A. (1994). Warum Incentive-Systeme oft versagen. Harvard Business Manager, 94(2), 15-23. Available at: https://link.springer.com/content/pdf/bbm\%3A978-3-663-08510-2\%2F1.pdf.

48. Kraus, R., \& Woschée, R. (2018a). Commitment und Identifikation mit Projekten. In Angewandte Psychologie für das Projektmanagement (pp. 187-206). doi: https://doi.org/https://doi.org/10.1007/978-3-662-53929-3_10

49. Kraus, R., \& Woschée, R. (2018b). Projektmanagement in Teams. In Angewandte Psychologie für das Projektmanagement (pp. 331-350). Available at: https://doi.org/10.1007/978-3-662-53929-3_17

50. Krieg, H.-J. (2010). Reizwort Bonus - Sinn oder Unsinn variabler Vergütung. In Führen mit Zielen (pp. 151-177). doi: https://doi.org/10.1007/978-3-8349-6311-6_9

51. Kühl, D. (2016). Empirische Ergebnisse aus drei Einzelfallstudien. In Balanceorientierte Führung (pp. 81-259). doi: https://doi.org/10.1007/978-3-658-14299-5

52. Kuznets, S. (1946). National product since 1869. Available at: https://dspace.gipe.ac.in/xmlui/bitstream/handle/10973/26159/GIPE-013542.pdf?sequence=3

53. Langhoff, T., \& Schröder, S. (2015). Innovationskompetenz im demografischen Wandel. In Innovationskompetenz im demografischen Wandel (pp. 43-197). doi: https://doi.org/10.1007/978-3-658-09159-0

54. Maier, G. W. (2015). Definition» extrinsische Motivation «| Gabler Wirtschaftslexikon. Available at: Wirtschaftslexikon.Gabler.De website: http://wirtschaftslexikon.gabler.de/Archiv/57321/extrinsische-motivationv5.html

55. Maier, G. W. (2018). Gabler Wirtschaftfslexikon, Definition intrinsische Motivation. Available at: 2018 website: https://wirtschaftslexikon.gabler.de/definition/intrinsische-motivation-41764/version-265123

56. Maier, G. W., \& Kirchgeorg, M. (2018). Gabler Wirtschaftfslexikon, Definition Motivation. Available at: 2018 website: https://wirtschaftslexikon.gabler.de/definition/motivation-38456/version-261879

57. Marx, K. (1887). Capital: A Critique of Political Economy. In Kapital English. doi: https://doi.org/10.1002/ejoc.201200111

58. Maslow, A. H. (1943). A Theory of Human Motivation. Psychological Review, 50(4), 370-396. Available at: 
SocioEconomic Challenges, Volume 4, Issue 4, 2020

ISSN (print) - 2520-6621, ISSN (online) - 2520-6214

https://psycnet.apa.org/PsycARTICLES/journal/rev/50/4

59. McCrae, R. R., \& Paul T. Costa, J. (1987). FiveFactorModel.pd.pdf. Journal of Personality an Social Psychology, 81-90. doi: $10.1007 / 978-1-4615-0763-5 \_2$

60. McKevitt, D., Carbery, R., \& Lyons, A. (2017). A profession but not a career? Work identity and career satisfaction in project management. International Journal of Project Management, 35(8), 1673-1682. doi: https://doi.org/10.1016/j.ijproman.2017.07.010

61. Mohan, K., \& Ahlemann, F. (2013). Strategisches Projektmanagement. In Strategisches Projektmanagement (pp. 37-58). doi: https://doi.org/10.1007/978-3-642-34761-0

62. Moser, K., Galais, N., \& Byler, A. (2018). Personalpsychologie im Projektmanagement. In Angewandte Psychologie für das Projektmanagement (pp. 101-124). doi: https://doi.org/10.1007/978-3-662-53929-3 6

63. Mühlenhof, M. C. (2018). Das Geheimnis der intrinsischen Motivation. Chefsache Intrinsische Motivation, 2140. doi: https://doi.org/10.1007/978-3-658-18307-3 4

64. Murray, H. A. (1938). Explorations in personality. Hoboken, NJ, USA: John Wiley \& Sons Inc. doi: https://doi.org/10.1002/0471264385.wei0507

65. Nagel, K., \& Schlegtendal, G. (1998). Flexible Entgeltsysteme: fair entlohnen-besser motivieren;[wirtschaftliche Modelle, erfolgreiche Praxisbeispiele, sofort umsetzbare Handlungsanweisungen]. Verlag Moderne Industrie. Available at: https://www.zvab.com/9783478363402/Flexible-Entgeltsysteme-3478363403/plp

66. Nerdinger, F. W. (1995). Motivation und Handeln in Organisationen: Eine Einführung. Stuttgart: Kohlhammer. Available at: https://www.amazon.de/Motivation-Handeln-Organisationen-EineEinf\%C3\%BChrung/dp/3170136003

67. Osterloh, M., \& Frey, B. S. (2000). Motivation, Knowledge Transfer, and Organizational Forms. Organization Science, 11(5), 538-550. doi: https://doi.org/10.1287/orsc.11.5.538.15204

68. Pfeffer, J. (1998). Sechs gefährliche Legenden über Arbeitsentgelte. Harvard Business Manager, (20), 41-50. Available at: https://www.zora.uzh.ch/id/eprint/11176/1/Brunner Bernard Zeitschrift ArbeitV.pdf

69. Piekenbrock, D. (2016). Gossensche Gesetze | bpb. Available at: Gabler Wirtschaftslexikon website: https://wirtschaftslexikon.gabler.de/definition/gossensche-gesetze-34811/version-258305

70. Pollet, E., \& Schnell, T. (2017). Brilliant: But What For? Meaning and Subjective Well-Being in the Lives of Intellectually Gifted and Academically High-Achieving Adults. Journal of Happiness Studies, 18(5), 1459-1484. doi: https://doi.org/10.1007/s10902-016-9783-4

71. Pryor, F. L. (2010). Capitalism and freedom? Economic Systems, 34(1), 91-104. doi: https://doi.org/10.1016/j.ecosys.2009.09.003

72. Radtke, B. (2014). Ansätze zur Erfassung und Beschreibung der Markenidentität. In Markenidentitätsmodelle (pp. 15-34). doi: https://doi.org/10.1007/978-3-658-04586-9

73. Rodorff, C. (2013). Managementvergütung und Principal-Agent-Theory. Forum Unternehmenskauf 2012, 229 254.doi: https://doi.org/10.5771/9783845244907-229

74. Rose, N. (2016). Geld macht glücklich , aber ... Die Zeit, 33. Available at: https://www.zeit.de/karriere/beruf/2016-08/gehalt-geld-glueck-zufriedenheit-einkommen/komplettansicht?print

75. Ryan, R. M., \& Deci, E. L. (2000). Intrinsic and Extrinsic Motivations: Classic Definitions and New Directions. Contemporary Educational Psychology, 25(1), 54-67. doi: https://doi.org/10.1006/ceps.1999.1020

76. Ryschka, J., Tietze, K.-O., Schneider, P., Wilke, J., Allmendinger, K., Schmidt, J. M., ... Michael Hess. (2005). Instrumente und Techniken der Personalentwicklung. In Praxishandbuch Personalentwicklung (pp. 77-267). doi: https://doi.org/10.1007/978-3-663-11137-5_4

77. Schares, C. (1993). Gewinn-und Kapitalbeteiligung von Arbeitnehmern-Ein Überblick über neuere Forschungsergebnisse. Zeitschrift Für Wirtschaftspolitik, 42, 179-218. doi: /https://doi.org/10.1515/zfwp-1993$\underline{0110}$

78. Schnabel, V. U. (2019). Die Kraft der großen Sache. DIE ZEIT, 1, 35-36. Available at: https://www.zeit.de/2019/01/sinn-leben-suche-sinnkrise-depression-psychologie-

zufriedenheit/komplettansicht?print

79. Schmalenbach, M. (2019). Sacrifice Sacrifice of the passion passion. DIE ZEIT, 2, 59. Available at: https://www.zeit.de/2019/02/burn-out-traumjob-leidenschaft-ueberarbeitung-ausbeutung/komplettansicht

80. Schnell, T. (2016). Psychologie des Lebenssinns - Tatjana Schnell - Google Books psychologie des lebenssinns. Available at: https://www.springer.com/de/book/9783662489215 
81. Schoper, Y. P. D., \& Schaden, B. (2015). Gehalt und Karriere im Projektmanagement 2015. Available at: https://www.gpm-ipma.de/fileadmin/user_upload/GPM/Know-How/GPM_Studie_GehaltKarriere_2015_ES.pdf

82. Schulz, V., \& Schulz, V. (2000). Anreizanalyse. In Nichtmaterielle Anreize als Instrument der Unternehmungsführung (pp. 87-161). doi: https://doi.org/10.1007/978-3-322-97646-8_4

83. Schwaab, M.-O., Bergmann, G., Gairing, F., \& Kolb, M. (2010). Führen mit Zielen. doi: https://doi.org/10.1007/978-3-8349-6311-6

84. Siebert, J. (2006). Die Studie „Leadership Excellence“. In Führungssysteme zwischen Stabilität und Wandel (pp. 189-328). doi: https://doi.org/10.1007/978-3-8350-9075-0_4

85. Slimka, D., Kampkötter, P., \& Grunau, P. (2018). Forschungsbericht 507, Bericht zum Forschungsmonitor "Variable Vergütungssysteme." Tübingen, Nürnberg, Köln. Available at: https://www.ssoar.info/ssoar/handle/document/58072

86. Stehr, C., Dziatzko, N., \& Struve, F. (2019). Corporate Social Responsibility und interkulturelle Kompetenz: Auflösung von unternehmensinternen Wertekonflikten anhand von Lösungsansätzen aus dem interkulturellen Kontext. In CSR und Interkulturelles Management (pp. 27-59). doi: https://doi.org/10.1007/978-3-662-55230-8

87. Suntum, P. D. U. van. (2005). Der gerechte Lohn und das Recht auf Arbeit. In Die unsichtbare Hand (pp. 59-71). doi: https://doi.org/10.1007/3-540-27688-2 6

88. Swonke, S., \& Schneider, C. (2013). Projektmanagement im Energiebereich. In Projektmanagement im Energiebereich (pp. 201-222). doi: https://doi.org/10.1007/978-3-658-00267-1

89. Sydow, J. (2012). Kooperatives Verhalten in zwischenbetrieblichen Projekten. Berlin. Available at: https://www.wiwiss.fu-berlin.de/fachbereich/bwl/management/sydow/media/pdf/Veroeff-Sydow-01-20161.pdf

90. Thaler, R. H. (2000). From homo economicus to homo sapiens. Journal of Economic Perspectives, 14(1), 133141. doi: https://doi.org/10.1257/jep.14.1.133

91. Tom, E., Uske, S., \& Lindenberg, K. (2008). Moderne Projektsteuerung in einer mehrdimensionalen Matrixorganisation. In Anlaufmanagement in der Automobilindustrie erfolgreich umsetzen (pp. 65-79). doi: https://doi.org/10.1007/978-3-540-78407-4_6

92. Tommasi, M., \& Weinschelbaum, F. (2007). Centralization vs. decentralization: A principal-agent analysis. Journal of Public Economic Theory, 9(2), 369-389. doi: https://doi.org/10.1111/j.1467-9779.2007.00311.x

93. Tondorf, K. (1996). Dynamik in der Lohntüte.(Flexibilisierung in der Entlohnung). Die Mitbestimmung, (Juni), 31-33. Available at: https://link.springer.com/content/pdf/bbm\%3A978-3-322-97636-9\%2F1.pdf

94. Tuckmann, B. W. (1965). Developmental sequences in small groups. Psychological Bulleti, (63), 348-399. Available at: https://www.semanticscholar.org/paper/DEVELOPMENTAL-SEQUENCE-IN-SMALLGROUPS.-Tuckman/678da5a8d7016cbd57fd741f5e62fc60d8eb5c4e

95. Twain, M. (1876). Tom Sawyer and Huckleberry Finn - Complete edition. Anaconda Publishing House. Available at: https://www.abebooks.com/book-search/title/tom-sawyer/author/mark-twain/first-edition/pub-min/1876/pubmax/1876/pics/sortby/1/n/200000237/

96. von Hülsen, H.-C., \& Kopiske, M. (2017). Geld verteilen oder Performance entwickeln, Trendstudie Performance Management 2017. Available at: http://assets.kienbaum.com/downloads/Performance-Management-Studie-2017Kienbaum.pdf?mtime $=20170926102302$

97. Weber, T., \& Beck, M. (2015). SONDERZAHLUNGEN Eine Analyse auf Basis der. In Staristisches Bundesamt, WISTA. Available at: https://www.destatis.de/DE/Publikationen/WirtschaftStatistik/2015/04/SonderzahlungenDeutschland 042015.pd f? blob=publicationFile

98. Wetzker, K., \& Strüven, P. (2016). Der enttarnte Stratege. doi: https://doi.org/10.1007/978-3-662-48696-2

99. Wilson, T. D., \& Gilbert, D. T. (2005). Affective Forecasting: Knowing What to Want. Current Directions in Psychological Science, June. doi: https://doi.org/10.1111/j.0963-7214.2005.00355.x

100. Windeler, A., \& Wirth, C. (2010). Netzwerke und Arbeit. In Handbuch Arbeitssoziologie. doi: https://doi.org/10.1007/978-3-531-92247-8 19

101. Wohlwender, A. (2014). Analyse der Wissenskommunikation in einer Matrixorganisation. doi: https://doi.org/10.1007/978-3-658-07518-7

102. Zwerenz, D. (2019). Brand Management: Organizational Changes in Project Management. Marketing and Management of Innovations, 6718(2), 253-265. doi: https://doi.org/10.21272/mmi.2019.2-22. 